\title{
Analysis of the Risk Factors of Premature Labor: Scoping Review
}

\author{
$1^{\text {st }}$ Devi Nurhayati \\ Midwifery Study Program Applied \\ Bachelor Program, \\ Faculty of Health Science, \\ Universitas 'Aisyiyah Yogyakarta, \\ Jl. Siliwangi (Ring Road Barat) No. 63, \\ Mlangi, Nogotirto, Gamping, Sleman, \\ Yogyakarta, 55292 \\ Indonesia \\ 05devinurhayati@gmail.com
}

\author{
$2^{\text {nd }}$ Sulistyaningsih \\ Faculty of Health Science, \\ Universitas 'Aisyiyah Yogyakarta, \\ Jl. Siliwangi (Ring Road Barat) No. 63, \\ Mlangi, Nogotirto, Gamping, Sleman, \\ Yogyakarta, 55292, \\ Indonesia \\ sulistyaningsih@unisayogya.ac.id
}

\begin{abstract}
Preterm labor globally is the leading cause of death in children under 5 years of age. Indonesia is the fifth country with the number of preterm births in the world. The exact cause of preterm labor is unknown, various causes and factors are suspected as the cause of preterm labor. Objective to analyze the risk factors associated with the incidence of preterm labor. Method scoping review with PRISMA flowchart. Identify a research question with the PEOS framework. The selection of articles published from 2010-2020 uses the Pubmed, Wiley, and Garuda databases with keywords. The assessment of the article uses the critical appraisal. The identification results were 183 articles. After duplication screening, title, abstract relevance, and inclusion and exclusion criteria, 10 articles had grade $\mathbf{A}$. The conclusion that the most dominant maternal risk factors for preterm labor were history of preterm labor, history of SC, gestation interval less than 12 months and active smoker or tobacco users. Fetal risk factors include intrauterine fetal death and fetal anomaly. The dominant clinical risk factors are antepartum hemorrhage, gestational diabetes, hypertension with pre-eclampsia.
\end{abstract}

\section{Keywords_- preterm labor, risk factors, scoping review}

\section{INTRODUCTION}

Preterm labor is the main cause of death in children under 5 years of age, Indonesia is the fifth country with the number of preterm births in the world[1]. Premature labor is childbirth that occurs before the fetus is 37 weeks old. Premature labor affects the infant mortality rate each year, it occurs due to immaturity of the baby's organ systems[2].

Various causes and factors are suspected as the cause of preterm labor. The exact cause of preterm labor is unknown. The causes of preterm labor are not singular but multicomplex[2]. Identifying the factors that influence and preventing preterm labor is needed. A better understanding of the risk factors for preterm labor and an estimated increased incidence of preterm labor is needed to improve access to effective obstetric and neonatal care[3]. The purpose of this review is to analyze the risk factors for preterm labor.

\section{METHOD}

The review method is a scoping review, namely categorizing or classifying the literature from the results of article selection using PRISMA flowchart (Figure 1) [4]. Identify research questions using the PEOS framework (population, exposure, outcomes, study design). The population is maternal. Exposure is all of the risk factors for preterm labor. The outcome was premature labor. Research design is all research both quantitative and qualitative. Identification of research articles from the PubMed, Willey, and Garuda databases. Article screening is conducted on duplicate articles, title relevance and abstract. Full text eligibility criteria used inclusion and exclusion criteria. The inclusion criteria consist of original research, human research, in English or Indonesian, publications from 20102020 , research in all developed and developing countries. The exclusion criteria were paid articles, risk factors for premature incidence with comorbidities, such as HIV, cancer, malaria, HPV, tumors. Assessment of the quality of articles included in the review uses a critical appraisal using the Grade Joanna Brigss Institute (JBI) with grades A[5].

\section{RESULT AND DISCUSSION}

\section{A. Result}

Based on the 10 articles selected, there are several characteristics, namely country of origin, research design, and grade of the article. The characteristics of the country of origin of the 10 articles were found in 8 countries with the characteristics of developed and developing countries. Developed countries consist of 4 continents, namely the American continent (Philadelphia, California and Utah), the European continent (Belgium and Finland), the Asian continent (Japan), and the Australian continent (Western Australia). The Characteristics of Developing Countries come from the African Continent (Tanzania). There are 3 characteristics of the research method, namely the design case control, cohort, and experiment. Of the 10 articles there were case control 2 grade A articles, a cohort study 6 grade $\mathrm{A}$ articles, and 2 experimental grade $\mathrm{A}$ articles. 


\section{B. Discussion}

Table 1 shows the risk factors that affect preterm labor are:

1. Maternal Risk IbuFactors

a. Active smoker

The first article calculates the prevalence of active smoking as a risk factor for preterm labor in $39 \%$ of the total population[6]. The sixth article conducted an analysis controlling for confounding factors, namely tobacco users with a value $(\mathrm{aOR}=2.33)$ [12]. This is in line with other studies that found the value $(\mathrm{aOR}=$ 1.48) of women who smoked during pregnancy had a higher risk for preterm birth, and especially for preterm labor which was medically indicated [16].

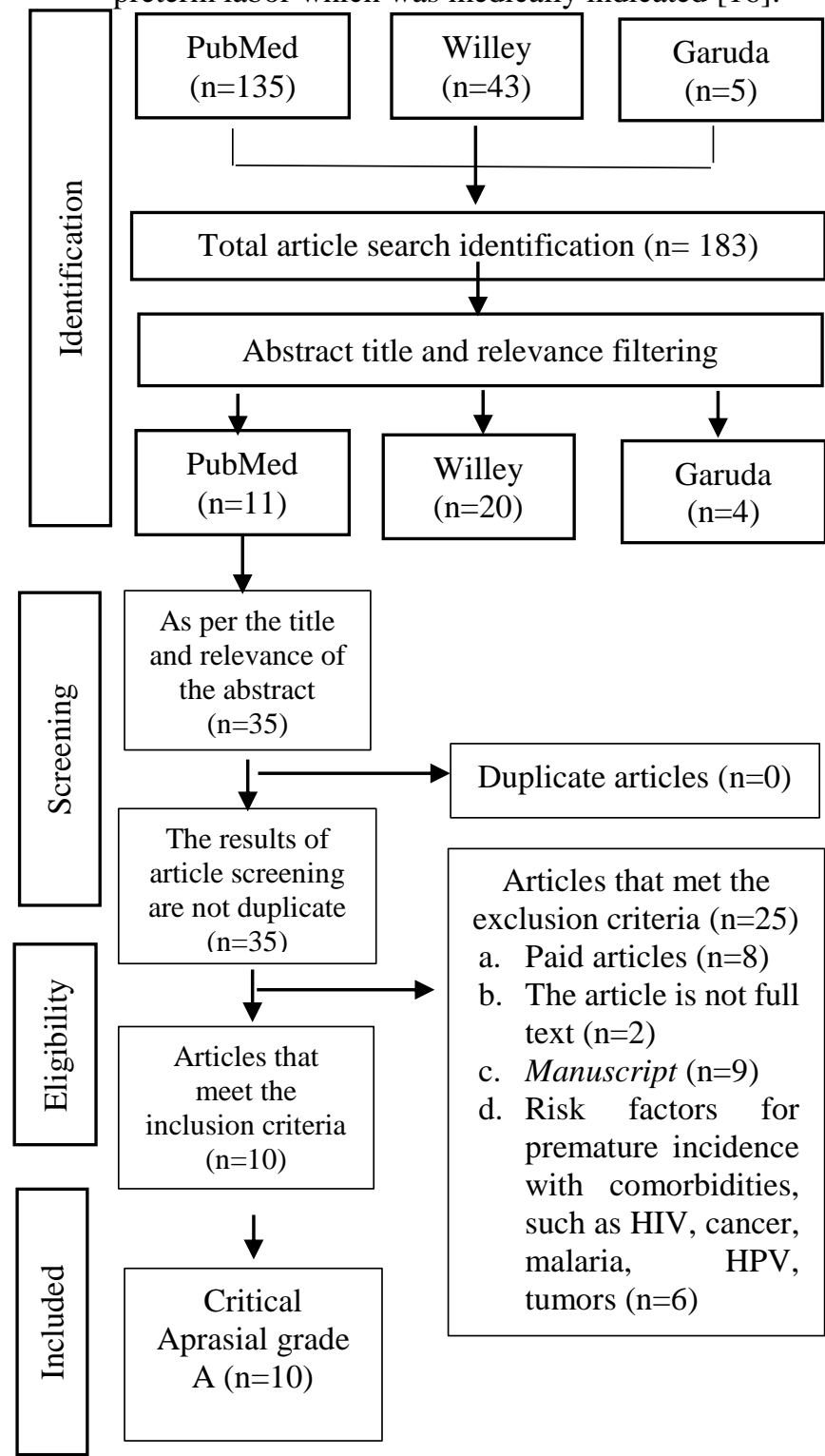

Figure 1. PRISMA Flowchart

b. Low literacy or education

The first article discusses the low literacy or knowledge of mothers as one of the factors that influence the occurrence of preterm labor with a prevalence value of $22 \%$ in Philadelphia, United States[6]. The results of the study support research in Lampung, Indonesia that there is a significant relationship between preterm labor and knowledge with a p value (0.011) with a prevalence of insufficient knowledge of 39\% [17].

The third article analyzes the related education of mothers to the incidence of preterm labor. The use of research methods with RCTs showed that mothers who did not receive education were a risk factor for preterm labor with a $\mathrm{p}$ value $<0.001$. Pregnant women with low education level experienced preterm labor with $\mathrm{p}$ value $=0.011(\mathrm{p}<0.05)[7]$. Low maternal education will affect the mother's mindset and decisions made on her health [22].

c. Housing instability

The first article analyzes housing instability as a risk factor affecting preterm labor with a prevalence of $88 \%$. Housing instability is described as the physical condition of the house, including money to pay late rent or utility bills, relocation services, or mediation to resolve disputes between landlords / tenants[6]. The issue of settlements in Indonesia is a problem that is currently being discussed a lot, especially those related to urban settlements. Starting from the problem of slum settlements [18], illegal settlements, and eviction of housing buildings[19]. This can affect the health of the family, including women who experience preterm labor, it's just that no research has been found in Indonesia that discusses this.

d. Maternal age

The third article using the RCT research method stated that mothers who are less than 25 years of age are at risk of experiencing preterm labor with a $\mathrm{p}$ value $<0.001[7]$. The tenth article stated that maternal age $<24$ years is more at risk $(\mathrm{aOR}=1.13)$ [10]. Another study showed that there was a significant relationship between age and preterm labor, the age group <20 years and $>35$ years experienced $51.7 \%$ of preterm labor with a p-value $=0.000$ [20].

e. Nullipara (never gave birth)

The third article using the RCT method stated that nulliparous mothers (who had never given birth) were at risk of experiencing preterm labor with a $\mathrm{p}$ value $<0.001[7]$. The fifth article was nulliparous as a confounding factor with a value $(\mathrm{aOR}=2.08)$ [11]. These results support other studies conducted showing that as many as $30(43.5 \%)$ pregnant women with parity 1 or $\geq 4$ experienced preterm labor and as many as $39(56.5 \%)$ pregnant women with parity of 2-3 babies experienced preterm labor. Statistical test results obtained $\mathrm{p}$ value $=0.049(\mathrm{p}<0.05)$ [21]

f. Body Mass Index (BMI)

BMI is one way to determine nutritional status by comparing body weight and height[23]. Of the 10 articles selected, there were 2 articles that analyzed BMI as a risk factor for preterm labor. The tenth article shows that mothers with less BMI (17-18.49 $\left.\mathrm{kg} / \mathrm{m}^{2}\right)$ with $\mathrm{aRR}=1.54$, less BMI $\left(16-16.99 \mathrm{~kg} / \mathrm{m}^{2}\right)$ with $\mathrm{aRR}=1.41$, BMI less $\left(<16 \mathrm{~kg} / \mathrm{m}^{2}\right)$ with $\mathrm{aRR}=$ 1.22 [8]. The fourth article with the value $(\mathrm{aOR}=$ 1.18) [10]. BMI as a risk factor for preterm labor.

g. Gestation interval

The sixth article stated that the pregnancy interval of less than 12 months was at risk of experiencing preterm labor with a value $(\mathrm{aOR}=2.13)$ [11] while the 
seventh article scored $(\mathrm{aOR}=1.17)$ [10]. The fifth article showed that the pregnancy interval was less than 18 months with a value of $(\mathrm{aOR}=1.37)$ [12], while the seventh article produced a pregnancy interval of more than 60 months with an aOR value of 1.1 [13]. The gestation distance is the distance between the current pregnancy and the previous pregnancy. A gestation interval of less than 2 years is considered a high risk because it can cause complications in childbirth[24]. 
Table 1. Article Mapping Results

\begin{tabular}{|c|c|c|c|c|c|c|c|c|}
\hline $\begin{array}{c}\text { Num } \\
\text { ber }\end{array}$ & $\begin{array}{c}\begin{array}{c}\text { Risk Factors for Premature } \\
\text { Labor }\end{array} \\
\end{array}$ & Prevalence & $\underset{\text { Value }}{p}$ & aRR & OR & aOR & Researcher & $\begin{array}{l}\text { Article } \\
\text { coding }\end{array}$ \\
\hline \multirow[t]{26}{*}{1.} & Maternal Risk Factors & & & & & & & \\
\hline & \multirow{2}{*}{ Active smoker and tobacco users } & $39 \%$ & - & - & - & - & [6] & A1 \\
\hline & & - & - & - & - & 2.33 & [12] & A6 \\
\hline & \multirow[t]{2}{*}{ Low literacy/education } & $22 \%$ & - & - & - & - & [6] & A1 \\
\hline & & - & $<0.001$ & - & - & - & [7] & A3 \\
\hline & Housing instability & $83 \%$ & - & - & - & - & {$[6]$} & A1 \\
\hline & Maternal age $<25$ years & - & $<0.001$ & - & - & - & [7] & A3 \\
\hline & Maternal age $<24$ years & - & - & - & - & 1.13 & [11] & A10 \\
\hline & \multirow[t]{2}{*}{ Nullipara } & - & $<0.001$ & - & - & - & [7] & A3 \\
\hline & & - & - & - & - & 2.08 & [11] & A5 \\
\hline & Less Body Mass Index $(17-18,5)$ & - & - & - & - & 1.18 & {$[10]$} & A10 \\
\hline & Less Body Mass Index $(16-16,99)$ & - & - & 1.22 & - & - & {$[8]$} & A4 \\
\hline & Less Body Mass Index $(<16)$ & - & - & 1.41 & - & - & [8] & A4 \\
\hline & \multirow[t]{3}{*}{ History of SC } & - & - & 1.54 & 2.30 & - & [9] & A9 \\
\hline & & - & - & - & - & 2.20 & {$[12]$,} & A6 \\
\hline & & & & & & 1.2 & {$[13]$} & A7 \\
\hline & \multirow[t]{3}{*}{ History of preterm labor } & - & - & - & 4.22 & - & [9] & A9 \\
\hline & & - & - & - & - & 2.26 & [11] & A9 \\
\hline & & - & - & - & - & 5.8 & {$[13]$} & A10 \\
\hline & History of abortion & - & - & - & 1.63 & - & [9] & A5 \\
\hline & \multirow[t]{2}{*}{ Gestation interval $<12$ months } & - & - & - & - & 2.13 & [11] & A6 \\
\hline & & - & - & - & - & 1.17 & {$[10]$} & A7 \\
\hline & Gestation interval $<18$ months & - & - & - & - & 1.37 & {$[12]$} & A5 \\
\hline & Gestation interval >60 months & - & - & - & - & 1.1 & {$[13]$} & A7 \\
\hline & Black race & - & - & - & - & 1.1 & [13] & A7 \\
\hline & Gaining weight during pregnancy & - & - & - & - & 1.14 & {$[10]$} & A10 \\
\hline \multirow[t]{3}{*}{2.} & \multicolumn{8}{|l|}{ Fetal Risk Factors } \\
\hline & Intrauterine Fetal death & - & - & - & - & 1.99 & {$[10]$} & A10 \\
\hline & Fetal anomaly & - & - & - & - & 1.59 & [10] & A10 \\
\hline \multirow[t]{19}{*}{3.} & \multicolumn{8}{|l|}{ Clinical Risk Factors } \\
\hline & \multirow[t]{2}{*}{ Urinary tract infection } & $57 \%$ & - & - & - & - & {$[6]$} & A1 \\
\hline & & - & - & - & 1.08 & - & [9] & A9 \\
\hline & Periodontal & $59 \%$ & - & - & - & - & [6] & A1 \\
\hline & Clinical depression & $17 \%$ & - & - & - & - & {$[6]$} & A1 \\
\hline & Ureaplasma species (U. spp.) & - & - & - & 1.64 & - & {$[14]$} & $\mathrm{A} 2$ \\
\hline & V Leiden & - & - & - & 2.9 & - & {$[15]$} & A8 \\
\hline & History of hypertension & - & - & - & - & 1.3 & {$[13]$} & A7 \\
\hline & Hypertension & - & - & - & 1.7 & - & [9] & A9 \\
\hline & \multirow[t]{2}{*}{ Hypertension with pre-eclampsia } & - & - & - & - & 2.1 & {$[13]$} & A7 \\
\hline & & - & - & - & - & 1.5 & {$[13]$} & A7 \\
\hline & Pre-eclampsia & - & - & - & 1.56 & - & [9] & A7 \\
\hline & Asthma & - & - & - & 1.08 & - & [9] & A9 \\
\hline & Herpes genetalia & - & - & - & 0.96 & - & [9] & A9 \\
\hline & \multirow[t]{2}{*}{ Diabetes gestasional } & - & - & - & 2.47 & - & [9] & A9 \\
\hline & & - & - & - & - & 2.0 & [13] & A7 \\
\hline & Antepartum Hemmorhage (APH) & - & - & - & 5.92 & - & [9] & A9 \\
\hline & \multirow{2}{*}{ Anemia } & - & - & - & 0.87 & - & [9] & A9 \\
\hline & & - & - & - & - & 1.1 & [13] & A7 \\
\hline
\end{tabular}


h. History of Premature Labor

There are 3 articles that analyze the history of preterm labor. The ninth journal has an OR value of 4.22 [9]. The ninth and tenth articles state as a confounding factor with a value of $\mathrm{aOR}=2.26$ [11] and a value of $\mathrm{aOR}=5.8$ [13]. Pregnant women who had a history of preterm birth 1 time had the probability of giving birth to a preterm baby again by $14.3 \%$ and increased to $28.1 \%$ in women who had a history of preterm birth twice [25].

i. History of Sectio Caesarea (SC)

There are 3 articles that analyze the history of caesarean section as a risk factor for preterm labor. The ninth article with $\mathrm{OR}=2.30$ [9]. The sixth article history of SC as a confounding factor with aOR value $=2.20$ [12] while the seventh article has a value of $\mathrm{aOR}=1.22$ [13]. A history of labor with a caesarean section does not have a causal relationship with preterm birth but rather a result of delivery indicated for maternal or fetal reasons caused by obstetric complications such as Pregnancy-induced hypertension (PIH) and Antepartum pregnancy hemorrhage (APH) [26]

j. Black Race

Only the seventh article analyzed black race as one of the confounding factors for preterm labor with aOR = 1.1. Research has considered the fundamental genetic variations that can contribute to racial differences in preterm birth [13]. TNF $\alpha$ and SERPINH1 were shown to be candidate genes for preterm birth in AfricanAmericans [27]

k. Weight Gain During Pregnancy

Only the tenth article analyzed weight gain during pregnancy as a confounding factor for preterm labor with $\mathrm{aOR}=1.14[10]$. Another study found a $\mathrm{p}$-value of 0.003 , which means that there is a relationship between nutritional status and preterm labor. If the mother at the time before and during pregnancy lacks nutritional intake and weight gain is less at risk of causing preterm labor[28].

1. History of Abortion

Only the fifth article analyzed history of abortion as a risk factor for preterm labor with an OR $=1.63$ [9]. History of abortion has been associated with preterm labor due to post-abortion effects, curettage action. As a result of the uterus that has received curettage and the result of the cervical muscle being stimulated to remain open during curettage, it will increase the risk of cervical incompetence in bearing the weight of pregnancy[29].

\section{Fetal Risk Factors}

a. Intrauterine Fetal death

Only the tenth article analyzed the associated fetal death as a confounding factor for preterm labor with an $\mathrm{aOR}=1.99$ [10]. Other studies show the $\mathrm{p}$ value $=$ 0.241 and the OR value: 1.792 . This intrauterine fetal death had a 1,792 times chance of incidence of preterm labor compared with non-fetal death, but it was not statistically significant [30].

b. Fetal anomaly

Only the article analyzed fetal anomaly as one of the confounding factors for preterm labor with aOR value
$=1.59[10]$. Congenital fetal anomalies are structural or functional anomalies that occur during intrauterine life. Also called birth defects, congenital defects, or congenital disorders, this condition develops before birth and can be identified before or at birth, or at a later date. An estimated $6 \%$ of babies worldwide are born with congenital defects, resulting in hundreds of thousands of related deaths. However, the true number of cases may be much higher because statistics do not frequently consider terminated pregnancies and stillbirths [31].

3. Clinical Risk Faktors

a. Urinary tract infection

There are 2 articles that analyze the associated UTI as a risk factor for preterm labor. The first article stated that the prevalence of UTI in preterm labor was 57\% [6]. Meanwhile, the ninth article got the result of OR $=1.08$ [9]. Anatomical and functional changes of pregnancy can increase the risk of urinary tract infections [32].

b. Periodontal Disease

Only the first article analyzed periodontal disease with a prevalence of 59\%[6]. Periodontal disease, a chronic oral infection of gram-negative bacteria, can cause chronic disruption through cytokines, exotoxins, and endotoxins that stimulate prostaglandin synthesis which will initiate uterine contractions[33]. There are no studies that state periodontal as a risk factor for preterm labor.

c. Clinical Depression

Only the first article discussed clinical depression occurring in preterm labor with a prevalence of $17 \%$ [6]. Clinical depression affected preterm birth with an $\mathrm{OR}=11.46$ [34]. The presence of physical or psychological stress causes premature activation of the Pituitary Adrenal Hypothalamus resulting in uteroplastic insufficiency and stress conditions in the fetus. This causes an increase in the hormones estrogen and adrenal hormones which cause uterine contractions, leading to preterm labor [35].

d. Ureaplasma Species (U. Spp)

Only the second article used a cohort study to analyze the associated Ureaplasma spp as a risk factor for preterm labor with an $\mathrm{OR}=1.64$ [14]. Ureaplasma spp is the most common organism isolated from amniotic fluid obtained from women who have had preterm labor [36].

e. V Leiden Factor

Only the eighth article using the case control method analyzed the $\mathrm{V}$ Leiden factor as a risk factor for preterm labor with an $\mathrm{OR}=2.9$ [15]. Factor V Leiden is an inherited thrombophilia. Thrombophilia may play a role in inducing preterm delivery by means of thrombosis in the placenta causing uteroplacental ischemia or oxidative stress, or by activating inflammatory mechanisms [15].

f. Hypertension with Pre-Eclampsia

Only the seventh article analyzed hypertension \& preeclampsia as risk factors for preterm labor. This study used a study group to analyze hypertension with a value of $\mathrm{OR}=1.7$ to analyze and analyze preeclampsia with a value of $\mathrm{OR}=1.56$ [9]. The 
development and state of pregnancy with increased pre-eclampsia increase preterm labor [37].

g. Asthma

Only the seventh article analyzed asthma as a risk factor for preterm labor using the study group with an $\mathrm{OR}=1.08$ result [9]. Mechanisms used to explain the increased risk of preterm labor in pregnant women with asthma as demonstrated through hypoxia and other physiological reporting of uncontrolled asthma, drugs used to treat asthma, and pathogenic or demographic factors (e.g. race, ethnicity, smoking, and obesity) ) related to asthma, but not actually caused by disease [38].

h. Herpes Genetalia

Only articles that analyzed genetalia analyzed protective factors as protective factors for preterm labor because they had an $\mathrm{OR}<1$ value, with an $\mathrm{OR}=$ 0.96 [9]. Herpes genetalia or Herpes simplex is the herpes caused by a ubiquitous, covert, and multiplier DNA virus belonging to the Herpesviridae family that is transmitted via mucous membranes and nonintact skin, which migrate to neural tissue, where they remain in a latent state. Herpes genetalia is an infection that can increase the risk of preterm labor [39].

i. Diabetes

Only the article analyzing the associated diabetes as a risk factor for preterm labor used the study group with an $\mathrm{OR}=2.47$ [9]. Women with gestational diabetes are at a higher risk of complications during pregnancy and during delivery, thus putting them at risk for preterm labor [40]

j. Antepartum Hemmorhage (APH)

Only the seventh article analyzed antepartum hemorrhage as a risk factor for preterm labor using the study group with the highest OR value of 5.92 [9]. Antepartum bleeding is life-threatening to maternal and fetal emergency obstetric emergencies. Pregnancies with pre-term bleeding should be prevented [37]

k. Anemia

There are 2 articles that analyze anemia as a risk factor for preterm labor. The ninth article with an $\mathrm{OR}=0.87$ [9]. The seventh article with the result of aOR value $=$ 1.1 [13]. Anemia in pregnant women occurs due to insufficient levels of hemoglobin in the blood [41]. This causes stress and hypoxia in the fetus which stimulates the Hypothalamus Pituitary Adrenal (HPA) resulting in uteroplastic insufficiency. This causes an increase in the hormones estrogen, prostaglandins and adrenal hormones which cause uterine contractions, leading to preterm labor [35].

The limitations of scooping review are that most of the 9 out of 10 articles come from developed countries so that it needs to be considered for generalization in developing countries. The articles obtained were varied and the results were different, so it was not possible to analyze the most dominant risk factors for preterm labor.

\section{CONCLUSION}

Based on the results of the scooping review, there are many risk factors that contribute to the incidence of preterm labor, including maternal, fetal and clinical risk factors. The most dominant risk factors for preterm labor based on the aOR value were history of preterm labor, history of SC, gestation interval less than 12 months and active smoker or tobacco users. Fetal risk factors include intrauterine fetal death and fetal anomaly. The dominant clinical risk factors are antepartum hemorrhage, gestational diabetes, hypertension with pre-eclampsia.

\section{ACKNOWLEDGMENTS}

The author would like to thank Mrs. Nurul Mahmudah who has provided input for the preparation of this scooping review.

\section{REFERENCES}

[1] WHO, "Preterm Birth," 2019. [Online]. Available: https://www.who.int/news-room/factsheets/detail/prterm-birth. [Accessed: 20-Nov-2019].

[2] A. Pribadi, J. C. Mose, and A. D. Anwar, Kehamilan Resiko Tinggi. Jakarta: CV Sagung Seto, 2015.

[3] K. Vakilian, M. Ranjbaran, M. Khorsandi, N. Sharafkhani, and M. Khodadost, "Prevalence of preterm labor in Iran: A systematic review and metaanalysis," Iran. J. Reprod. Med., vol. 13, no. 12, pp. 743-748, 2015.

[4] A. C. Tricco et al., "PRISMA extension for scoping reviews (PRISMA-ScR): Checklist and explanation," Ann. Intern. Med., vol. 169, no. 7, pp. 467-473, 2018.

[5] S. Moola et al., Chapter 7: Systematic reviews of etiology and risk. JBI, 2020.

[6] D. A. Webb, L. Mathew, and J. F. Culhane, "Lessons learned from the Philadelphia Collaborative Preterm Prevention Project: The prevalence of risk factors and program participation rates among women in the intervention group," BMC Pregnancy Childbirth, vol. 14, no. 1, pp. 1-10, 2014.

[7] A. Muhihi et al., "Risk factors for small-forgestational-age and preterm births among 19,269 Tanzanian newborns," BMC Pregnancy Childbirth, vol. 16, no. 1, pp. 1-12, 2016.

[8] A. I. Girsen et al., "Women's prepregnancy underweight as a risk factor for preterm birth: a retrospective study," BJOG An Int. J. Obstet. Gynaecol., vol. 123, no. 12, pp. 2001-2007, 2016.

[9] G. Hammond et al., "Changes in risk factors for preterm birth in Western Australia 1984-2006," BJOG An Int. J. Obstet. Gynaecol., vol. 120, no. 9, pp. 1051-1060, 2013.

[10] S. E. Simonsen, J. L. Lyon, J. B. Stanford, C. A. Porucznik, M. S. Esplin, and M. W. Varner, "Risk factors for recurrent preterm birth in multiparous Utah women: A historical cohort study," BJOG An Int. J. Obstet. Gynaecol., vol. 120, no. 7, pp. 863872, 2013. 
[11] M. Yamashita et al., "Incidence and risk factors for recurrent spontaneous preterm birth: A retrospective cohort study in Japan," J. Obstet. Gynaecol. Res., vol. 41, no. 11, pp. 1708-1714, 2015.

[12] L. F. Wong, J. Wilkes, K. Korgenski, M. W. Varner, and T. A. Manuck, "Risk factors associated with preterm birth after a prior term delivery," BJOG An Int. J. Obstet. Gynaecol., vol. 123, no. 11, pp. 17721778, 2016.

[13] L. L. Jelliffe-Pawlowski et al., "Maternal characteristics and mid-pregnancy serum biomarkers as risk factors for subtypes of preterm birth," BJOG An Int. J. Obstet. Gynaecol., vol. 122, no. 11, pp. 1484-1493, 2015.

[14] M. Breugelmans, E. Vancutsem, A. Naessens, M. Laubach, and W. Foulon, "Association of abnormal vaginal flora and Ureaplasma species as risk factors for preterm birth: A cohort study," Acta Obstet. Gynecol. Scand., vol. 89, no. 2, pp. 256-260, 2010.

[15] L. M. Hiltunen et al., "Factor V Leiden as a risk factor for preterm birth - a population-based nested case-control study," J. Thromb. Haemost., vol. 9, no. 1, pp. 71-78, 2011.

[16] M. H. Aliyu, O. Lynch, R. Saidu, A. P. Alio, P. J. Marty, and H. M. Salihu, "Intrauterine exposure to tobacco and risk of medically indicated and spontaneous preterm birth," Am. J. Perinatol., vol. 27, no. 5, pp. 405-410, 2010.

[17] R. Ningsih and N. Indrasari, "Faktor-Faktor Yang Berhubungan Dengan Kejadian Kelahiran Bayi Prematur," J. Kesehat. Metro Sai Wawai, vol. V, no. 2, pp. 95-100, 2012.

[18] I. Lestari and A. Sugiri, "Peran Badan Keswadayaan Masyarakat Dalam Penanganan Permukiman Kumuh Di Podosugih, Kota Pekalongan," Tek. Perenc. Wil. Kota, vol. 2, no. 1, pp. 30-41, 2013.

[19] R. P. Setiawan, "Penggusuran Permukiman Liar di Stren Kali Jagir: Sebuah Tinjauan dari Sisi Hukum dan Humanisme," Semin. Nas. Perumah. Permukim. dalam Pembang. Kota, vol. 1, no. October, pp. 0-12, 2010 .

[20] B. T. Carolin, "Faktor-Faktor Yang Berhubungan Dengan Kejadian Persalinan Preterm Di Rumah Sakit Muhammadiyah Taman Puring Kebayoran Baru Jakarta Selatan Periode januari-Juni Tahun 2017," J. Ilmu Keperwatan dan Kebidanan Nas., vol. 1, no. 1, 2019 .

[21] R. Wahyuni and S. Rohani, "Faktor-Faktor yang Mempengaruhi Persalinan Preterm," J. Aisyah J. Ilmu Kesehat., vol. 2, no. 1, pp. 61-68, 2017.

[22] E. Eliza, D. D. Nuryani, and R. Rosmiyati, "Determinan Persalinan Prematur di RSUD Dr. Abdul Moeloek," J. Kesehat., vol. 8, no. 2, p. 305, 2017.

[23] Kemenkes, "Kamus," Kementrian Kesehatan Republik Indonesia, 2020. [Online]. Available:
https://www.kemkes.go.id/index.php?txtKeyword=s tatus+gizi\&act=search-by-

map\&pgnumber $=0 \&$ charinde $x=\&$ strucid $=1280 \&$ ful lcontent $=1 \& \mathrm{C}$-ALL $=1$.

[24] A. B. Saifuddin, Ilmu Kebidanan. Jakarta: Yayasan Bina Pustaka Sarwono Prawirohardjo., 2015.

[25] Y. P. Zhang et al., "Risk Factors for Preterm Birth in Five Maternal and Child Health Hospitals in Beijing," PLoS One, vol. 7, no. 12, pp. 1-7, 2012.

[26] O. A. Mokuolu, B. M. Suleiman, O. O. Adesiyun, and A. Adeniyi, "Prevalence and determinants of preterm deliveries in the University of Ilorin Teaching Hospital, Ilorin, Nigeria," Pediatr. Rep., vol. 2, no. 1, pp. 11-14, 2010.

[27] S. E. Purisch and C. Gyamfi-Bannerman, "Epidemiology of preterm birth," Semin. Perinatol., vol. 41, no. 7, pp. 387-391, 2017.

[28] T. Anasari and I. Pantiawati, "Faktor-Faktor Yang Mempengaruhi Persalinan Preterm Di RSUD Prof. Dr. Margono Soekarjo Purwokerto," J. Kebidanan, vol. VIII, no. 01, pp. 94-109, 2016.

[29] E. D. Purwaningrum and A. I. Fibriana, "Faktor Risiko Kejadian Abortus Spontan," Higeia, vol. 1, no. 3, pp. 84-94, 2017.

[30] L. Meliati, “Analisis Faktor Faktor Yang Berhubungan Dengan Kejadian Persalinan Prematur Di RSUP NTB," J. Kesehat. Prima, vol. I, no. 2, pp. 1298-1307, 2013

[31] WHO, "Congenital anomalies," WHO, 2020. [Online]. Available: https://www.who.int/healthtopics/congenital-anomalies\#tab=tab_1. [Accessed: 21-Jul-2020].

[32] H. M. Masteryanto, G. Hardianto, H. T. Joewono, and E. B. Koendhori, "Infeksi Saluran Kemih Sebagai Faktor Risiko Terjadinya Ancaman Persalinan Preterm," Maj. Obstet. Ginekol., vol. 23, no. 2, p. $75,2015$.

[33] A. S. Parihar, V. Katoch, S. A. Rajguru, N. Rajpoot, P. Singh, and S. Wakhle, "Periodontal Disease: A Possible Risk-Factor for Adverse Pregnancy Outcome.," J. Int. oral Heal. JIOH, vol. 7, no. 7, pp. $137-42,2015$

[34] Susilawati, Y. Evayanti, and D. Anwarina, "Hubungan Stres Ibu Selama Kehamilan Dengan Kejadian Prematur Pada Ibu Bersalin Di Rsudpringsewu Tahun2016," J. Kebidanan, vol. 3, no. 1, pp. 34-38, 2017.

[35] R. Fauzy and E. Fourianalisyawati, "Hubungan antara Depresi dengan Kualitas Hidup pada Ibu Hamil Berisiko Tinggi The Relationship Of Depression With Quality Of Life In Pregnant Women At High Risk," J. Psikogenes., vol. 4, no. 2, pp. 206214, 2016.

[36] R. M. Viscardi, "Ureaplasma species: Role in diseases of prematurity," Clin. Perinatol., vol. 37, no. 2, pp. 393-409, 2010. 
[37] T. Nugroho, Obsgyn: Obstetri Dan Ginekologi Untuk Mahasiswa Kebidanan Dan keperawatan. Yogyakarta: Nuha Medika, 2012.

[38] J. A. Namazy and M. Schatz, "Asthma and pregnancy," J. Allergy Clin. Immunol., vol. 128, no. 6, pp. 1384-1385.e2, 2011.

[39] G. Straface, A. Selmin, V. Zanardo, M. De Santis, A. Ercoli, and G. Scambia, "Herpes simplex virus infection in pregnancy," Infect. Dis. Obstet. Gynecol., vol. 2012, 2012.

[40] WHO, "Diabetes," WHO, 2020. [Online]. Available: https://www.who.int/news-room/factsheets/detail/diabetes. [Accessed: 22-Jul-2020].

[41] A. B. Saifuddin, Buku Acuan Pelayanan Kesehatan Maternal dan Neonatal. Jakarta: Yayasan Bina Pustaka Sarwono Prawirohardjo., 2010. 